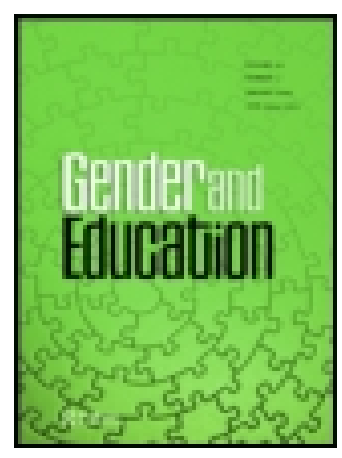

Gender and Education

\title{
Femina Academica: women 'confessing' leadership in Higher Education
}

\section{Emanuela Spanò}

To cite this article: Emanuela Spanò (2017): Femina Academica: women 'confessing' leadership in Higher Education, Gender and Education, DOI: 10.1080/09540253.2017.1336205

To link to this article: http://dx.doi.org/10.1080/09540253.2017.1336205

册 Published online: 22 Jun 2017.

Submit your article to this journal $\pi$

Џ Article views: 11

Q View related articles $\sqsubset$

View Crossmark data 


\title{
Femina Academica: women 'confessing' leadership in Higher Education
}

\author{
Emanuela Spanò \\ Social Sciences, Universita degli Studi di Napoli Federico II, Napoli, Italy
}

\begin{abstract}
This contribution explores how different policy discourses produce site-specific representations and self-representations of gender and leadership, which may reveal forms of subjectivation as well as spaces of resistance to hegemonic discourses. I will consider two different Higher Education policy systems: the UK system that since the 1980s has undergone rapid and radical changes that introduced market-oriented reforms profoundly influenced by the managerialist discourse in the form of New Public Management; the Italian system that still remains rooted in the bureaucratic and professional discourses despite some timid attempts to import the 'managerial recipes'. This contribution focuses on the construction of gender and leadership in different academic contexts 'mapping' different aspects connected to the gendered selfnarration of leadership. For this purpose, nine interviews of women occupying roles as middle managers in one of the largest universities of the South of Italy and in different universities in the UK, are discussed and compared.
\end{abstract}

\section{ARTICLE HISTORY}

Received 27 May 2016

Accepted 20 April 2017

\section{KEYWORDS}

Gender; leadership; Higher

Education; self-narration

\section{Introduction}

This contribution explores how different policy discourses produce site-specific representations and self-representations of gender and leadership, which may reveal forms of subjectivation as well as spaces of resistance to hegemonic discourses. To this end, a juxtaposition of narratives of women in middle-management positions within different university contexts has been proposed in order to understand what concepts of gender and leadership the women held. More specifically, I consider two different Higher Education (HE) policy systems: the UK system that since the 1980s has undergone rapid and radical changes that introduced market-oriented reforms profoundly influenced by the managerialist discourse in the form of New Public Management (Hall et al. 2015); the Italian system that still remains rooted in the bureaucratic and professional discourses despite some timid attempts to import the 'managerial recipes' (Clark 1983). ${ }^{1}$

To create a theoretical toolbox, firstly, I conceptualise policies as discourses. Discourses can be considered as heuristic tools which allow the different, sometimes contrasting logic underlying the policies and their implications, to come to light (Ball 2006). ${ }^{2}$ Secondly, I take 
into account the new forms of educational governance (Newman and Clarke 2009, 18; Serpieri 2012). Thirdly, being inspired by Tamboukou's Foucaultian approach to narratives (2003), I interpret women's practices of self-narration as specific forms of self-verbalisation, as 'renewed' examples of the confessional techniques (Foucault 1984, 1988).

The contribution draws from an empirical work that mapped the policy discourses mobilised by UK and Italian governments and universities around academic leadership and tries to unveil the role that those discourses play in shaping women leaders' subjectivities. Nine of the 24 narrative interviews of women occupying roles as middle managers ${ }^{3}$ in one of the largest universities of the South of Italy and in different universities in the UK are discussed and compared.

Among the most important findings, the analysis of the empirical material previously collected, identified an interesting myth that emerged from the intersection of gender and leadership: the myth of leadership. This myth advocates new 'forms' of leadership in order for an organisation to survive in a more complex and more competitive environment: leaders are expected to demonstrate authority and affective agency, but differently from the past they should also possess excellent interpersonal and communication skills. Those traits are still assumed to be the 'natural' domain of women. Moreover, figures used to describe other women leaders in both contexts were recognised and interpreted (Martin 1990).

Starting from this finding, in the first section of this work I critically analyse some aspects connected to the myth of leadership, trying to bring out concepts of gender and leadership the women of different university contexts held. In the second section, I explore another recurring theme in gender self-representations of interviewees connected to the stereotypical idea that women lead in particular ways thanks to their 'innate' soft skills. This is that women are 'naturally' competitive with other women and for this reason sisterhood and solidarity among women that much of the literature on women and leadership uncritically assumes, does not exist. Trying to understand whether these stereotyping assumptions 'travel' across the boundaries of the two different contexts considered, I also discuss some of the figures used to describe other women that have emerged in the narratives of both contexts. In conclusion, trying to be aware of not giving a universalistic interpretation of the empiric materials previously collected, I highlight some similarities and differences emerged from the juxtaposition of women leaders' narratives within the two different university contexts considered.

\section{Leadership: epimeleia or resistance?}

The UNESCO (1998) Declaration on Higher Education included a statement that HE 'should promote solidarity and equity', and it also included equality of access. Moreover, the restructuring of the HE field, supported by 'democratising' discourses such as merit or opportunity, diffused a natural 'faith' that the new university would provide the 'natural' achievement of gender equality (for example, through quality assurance polices). Consequently, gender equity has become frequently absent, as a category of analysis both in many research studies on $\mathrm{HE}$ and in the complex attempts of appraisal of the changing processes in place. ${ }^{4}$ However, the assumption that women have secured a level of opportunity and advantage in the workplace collides with the pattern of male prevalence in 
senior and middle leadership positions that is still visible in countries with diverse policies and gender equality legislation. ${ }^{5}$

Re-reading the narratives collected and following Fitzgerald (2014), I examine a specific aspect of the 'myth' ${ }^{6}$ that emerged on women and leadership, suggesting that women lead in particular ways. Trying to understand whether this stereotyping assumption 'travels' across the boundaries of the two different contexts considered, the central thesis that emerged is that women possess leadership 'natural qualities' that 'either confine them to roles as institutional housekeepers or limit their potential effectiveness at senior levels' (ivi, 22).

In the last decades, management journals, business press and a large part of the wider research literature advocate new 'forms' of leadership in order for an organisation to survive in a more complex and more competitive environment (Kay and Shipman 2014). Potent cultural templates, or scripts, circulate on how leaders should be and behave - often based on larger cultural and historical formations (Morley 2013). Leaders are expected to demonstrate authority and affective agency, but differently from the past they should also possess excellent interpersonal and communication skills.

Especially in the British context, where there has been a wider managerialist re-orientation of academic leadership, those popular scripts have started to connect leadership with traits that are collaborative, flexible and relationship oriented, and that can be summarised in David Goleman's popular term 'emotional intelligence' (1995). ${ }^{7}$

On the one hand, those traits are assumed to be the 'natural' domain of women. On the other, however, the language of leadership still extols virtues such as rationality, strategic vision, energy, commitments toughness etc., skills that women are expected to demonstrate yet men are assumed to 'naturally' possess. ${ }^{8}$ More in general, the (feminine) leadership myth reveals populist and essentialist discourses about women's styles of leadership that perpetuate a particular ideology about what leadership ought to look like and how women leaders in particular have to 'manage' power. These discourses have emerged in many of the narrations collected in the Italian context where paradoxically middlemanager roles are still inspired by bureaucratic and professional discourses. In this sense, the leadership myth assumes a cross-border and 'cross-discursive' dimension, revealing his nature of transnational cultural ideology (O'Reilly and Reed 2010).

Despite the fact that in both contexts many women interviewed recognise the necessity of undertaking repair work and mediate their own femaleness when 'disrupting' the male terrain of management (Connell 2006), for many of them emotionality, sensibility and power as 'care' represent virtues that women 'naturally' possess.

Self-narrations are complex and unstable discursive regimes in/through which the subject emerges as multiple, contradicted and heteronomous in relation to the social and cultural conditions that tend to define, control and dominate its very existence (De Lauretis 1987). For this reason, it is impossible to reduce women's 'confessions' to those essentialist discourses. But interestingly discourses on women's styles of leadership reintroduce 'traditional' gendered dichotomies opposing rationality/emotionality, masculine/feminine. As F. (direttrice di dipartimento) points out, in her own experience being a women leader means managing power as 'taking care of others'. Moreover, in her opinion the revaluation of 'new' feminine leadership qualities could undoubtedly advantage women in their academic career. This conception of 'feminine power', seem to 
recall Foucault's concept of epimeleia, interpreted as 'taking care of oneself and of others' (1984):

F (Italy): I think that I have been really influenced by gender because being a woman I have an idea of power and authority as sharing, as taking care of other people ... care of relationships, of academic community, of students and so on ... I realised that the restructuring of the Italian university may represent an advantage for women that can now compete in the academic workforce on the same terms as men. Merit, intellectual productivity, commitment, for the first time in the Italian HE history will be really recognised and rewarded. Moreover, what we need now is a feminine way of leading, that is to say more 'flexible' ways of managing, paying attention to people needs and feelings ...I think this could really help in this HE process of transformation!

If it is true that more than in the past leaders are required to demonstrate attention to the relational and emotional dimension of their leadership work, the need of managing and camouflaging this emotionality in order to become 'one of the boys' reveals the persistence of a negative perception of emotions, viewed as synonyms of irrationality (Putnam and Mumby 2000). ${ }^{9}$

Conversely, in many narratives collected in the British context discourses on 'women's styles of leadership' are critically interpreted as part of the technologies of gender ${ }^{10}$ (De Lauretis 1987) that reproduce and reinforce dominant gender regimes also in the academic field. The association of management and leadership work with qualities and skills traditionally linked with masculinity and men are reinforced by the persistent evidence of the under-representation of women in senior positions. Whereas women are often taking responsibilities for the domestic labour of teaching, administrating and more in general more likely to carry out activities of 'institutional housekeeping' that mainly represent an invisible labour.

For many women interviewed in the British context discourses on 'women's ways of leading' rest on the dangerous assumption that women are 'there for others' and are 'naturally' suited to promote and maintain the emotional well-being of the organisation. Less clear is whether these leadership styles help or hinder women's career progression in universities (Doherty and Manfredi 2006).

In La Volontè de savoir (1976), Foucault has argued that within relations of power, individuals and groups can find space to resist domination and exercise freedom. Power, in fact, is inextricably linked to resistance. 'Resisting' dominant discourses on gendered leadership can, for example, mean the adoption of a 'feminist', instead of 'feminine', way of leading. As V. argues:

V (UK): With my female colleagues I have a very collegial approach to leadership I really believe in team work and I always try to share responsibilities and duties ... I don't believe in a hierarchy, but I try to adopt a collaborative and cooperative way of leadership, which is not a feminine way of being a leader, but a feminist way, that's a big difference! And that can be extended also to other fields that are not just the academia ... I think it could really change things and be a way of resisting the performative academia, adopting a more inclusive and less individualistic way of leading.

Feminist leadership is characterised by an attempt to challenge the competitive individualism promoted by the performative academia that reproduces and confirms 'natural' characterisations of competition and jealousy and conflict among women. In the next paragraph, this other facet of the myth of leadership will be explored. 


\section{Women who hate other women: figures of 'successful' women}

As mentioned above, another recurring theme in gender self-representations of interviewees is that sisterhood and solidarity among women that much of the literature on women and leadership uncritically assumes does not exist. If is true that, as Blackmore and Sachs (2007) argue, the level of subjective perception and the one of system? interact, these stereotypes on relationship among women can strengthen specific 'gender regimes' (Connell 2006).

For instance, E. who identifies herself with feminism admits she felt disappointed with her female colleagues' criticisms and scarce solidarity:

E (UK): I am a feminist and you know what? I am so disappointed! When I entered the academy I thought that solidarity has to be there but it doesn't exist anymore ... The greatest opposition and criticism that I had as a leader is from my female colleagues... What they try to do is to be competitive to make you feel insecure as if you are not doing a good job and that's really sad and disappointing as a feminist! Coming back to my being a mother is that you would expect women even if they don't have children will understand you, but this is just an illusion!

This perception of women as the worst enemies of themselves is also shared by A., an Italian interviewee who interprets this 'innate' competitiveness as a prosecution of the childhood competition with the mother:

A (Italy): In my opinion the problem is that women are always at war with other women. That is why we still mean nothing in the academia! On the contrary, men create alliances to 'conquer' power, authority, career opportunities ... Women cannot do this! In some way they unconsciously reproduce the childhood competition with the mother, a mechanism that surely exerts a negative impact on their possibility of entering and managing the academia. For this reason when in the 70s Italian feminists' slogan was 'Woman is beautiful!' I felt a bit disappointed and jokingly replied: 'Being a woman is beautiful but to a certain extent!'

Strictly connected to this perception, 'disparaging' figures used to describe other women have emerged in both contexts. Among those, for example, in the Italian context the figure of a 'scoundrel' has been used to describe women who have been 'unscrupulous' in becoming successful in a male-dominated environment. A scoundrel is someone who breaks the law, has no morals. Most villains in movies and on television can be put in this category. Interestingly, this particular term is usually reserved for men. ${ }^{11}$ Feeling excluded from their female colleagues the 'scoundrels' probably start to emphasise their masculine characteristics (such as assertiveness, dominance or unscrupulousness) and stressing their difference with other women.

Moreover, as P. critically observes, performative culture promotes a male way of leading implicitly encouraging women to 'lead like men' and consequently distance themselves from other women:

P (UK): When women become leaders, they then have to manage power, decision making, they sort of start to act like men ... and in some sense the way they behave ... the fact that they are women doesn't make any difference... so in some sense they are much harder, much more driven from the performative culture, so in a sense there is this notion that you have to do this, you have to write, you have to ... You haven't done it so therefore there is a punishment ... which is a very male way of leading and what happened is that women 
feel that if they don't do that, they don't use this kind of discourse that men use they will not be seen as equal to men because they will be seen as leading in a soft way.

The 'police constable'12 is another gender-neutral figure that an Italian interviewee proudly adopts to define her 'a-gendered' way of leading. The 'police constable' represents the 'competent leader' who re-establishes 'order' exerting the authority given by the institutional 'uniform' he/she wears. As E. recalls:

E (Italy): I like my role of 'policeman-leader' ... I think is the best way of exerting my authority ... I remember last year my husband came to meet me in the department ... There were some colleagues obviously all men... My husband was very surprised at my assertive and professional attitude ... He told me: 'You are not a woman, you are a police constable!' ... I probably wear this 'uniform' in formal situations ... It is a kind of 'armour' I wear to protect myself, trying not to be hurt!

In this case, the 'police constable' figure subjectivates women as 'good' at their work as leaders for their capacity of camouflage their femininity, acting in a neutral and authoritative way in order to conform to masculine implicit norms. In this sense wearing a 'uniform' is also a strategy to protect themselves from the 'danger' of not 'fitting' normative patterns of femininity.

Some exclusively feminine figures, that are figures to which a masculine equivalent cannot be found, have also emerged. Among those, in the UK context, the well-known 'queen bee' (Mavin 2006) label has been attached to women who are perceived to be gatekeepers as they do not create pathways for their female colleagues. As M. recalls:

M (UK): There was a terrible woman professor when I started who when I was interviewed for the position proudly said 'you're the first woman we have interviewed for this position since I've been here'. She was one of those women who had got a position and kept other women out. Bit like a queen bee really ...

The 'Erinys' has also emerged as a 'powerful' figure. The 'Erinys' figure has been used to describe women who adopt negative and even 'ferocious' behaviours towards other women. This 'brutal ferocity' is recalled with fear by I.:

I (Italy): I wouldn't imagine I could feel so scared ... She is an Eryins! She exerts her power through threat and intimidation ... especially toward other women she is always cruel... She makes comments on the way other women wear, or make-up ... usually with her male colleagues... For me is really embarrassing ... Many times she pretends she doesn't even remember me and, for example, ask to an other (male) colleague with a loud voice: 'And who is she?' ... It's a nightmare really ...

In Greek mythology the Erinyes also known as Furies, were female chthonic deities of vengeance; they were sometimes referred to as 'infernal goddesses'. Depending upon authors, they are described as snake-hair, dog's heads, coal black bodies, bat's wings, and blood-shot eyes. In this sense, the Erinys figure represents a kind of 'ferocity', a 'fury' without control usually associated to the irrational sphere of femininity.

Finally, in the British narratives, the figure of Margaret Thatcher has been used to describe women who try to be 'more men than men', refusing any kind of gender identification. At this purpose, S. mentions a 'Margaret Thatcher's syndrome':

S (UK): The main British narrative about women of success is Margaret Thatcher ... is still the stereotype of masculine leadership and I think it also dominates British academia ... Women 
who have the 'Margaret Thatcher syndrome' usually refuse any gender identification and try to be 'more men then men' by adopting a very hard and masculine style of leadership!

In this sense, this figure represents one of the clearest examples of the fact that a successful woman does not always mean a step forward for women. Moreover, Margaret Thatcher especially resented being defined by her gender. She wasn't a feminist icon and she was not an icon for women. She was a prime minister who 'happened' to be a woman. In fact, she promoted only one woman to her cabinet, preferring instead to elevate men whom 'spitting image' memorably and, in certain instances, accurately, described as 'vegetables' (Freeman 2013).

\section{Conclusion: findings in contexts}

In drawing together narratives from women academics in Naples and across England, I have tried to be aware of not giving a universalistic interpretation of the empiric materials previously collected. In fact, it exclusively focuses on women's self-representations practices, overshadowing on purpose male representations of female ways of leading and exerting power.

Nevertheless and in conclusion, it is possible to highlight the 'cross-border' dimension of the (gendered) myth of leadership: the analysis of the narratives reveals that in national contexts characterised by different discursive configurations, such as Italy and UK, the gendered myth of leadership emerges and subjectivates women in similar ways. In fact, in both contexts women are paradoxically subjectivated as 'good' or 'bad' and valued for their capacity of 'fitting' normative patterns of femininity.

More specifically, from the narrative collected this 'transnational' dimension can be identified, firstly, in the 'cross-border' re-introduction of essentialist discourses of women's styles of leadership. In both contexts those discourses reinforce expectations that women's leadership should be based on care and nurture, on the control of emotions, on being self-sacrificing and displaying 'feminine' qualities (Fitzgerald 2014). Secondly, it emerges from the naturalisation of competition, jealousy and conflicts between women that surely exerts a negative impact on how women are viewed across the organisation. The fact that in both contexts women adopted negative figures - scoundrel, police constable, Eryins - to describe other women leaders on the one hand, offers 'evidence' of the naturalisation of competition and envy among them. On the other hand, those labels subjectivate women as 'good' or 'bad' and their work as leaders is valued only in the most marginal sense. Moreover, taking the 'Erinys' label as an example, it is interesting to highlight that there is not an equivalent label or figure to describe men who behave 'cruelly' towards their peers. Indeed, Fitzgerald argues, 'poor behaviour from men in leadership roles can be deemed as competitive and is rendered acceptable' $(2014,92)$. In fact, men in leadership positions are neither expected to support their women colleagues nor condemned when they fail to do so.

From the narratives collected it is also possible to highlight some differences between the contexts considered: while in the UK context narratives of resistance against the dominant discourse of managerialism have emerged, in the Italian one it is possible to record a diffuse 'faith' in a renovated version of the discourse of merit that the managerialist 'discursive imaginary' brought back. For example, in one of the accounts selected - that is 
exemplificative of many other interviews collected but not presented in this work F. (direttrice di dipartimento) argues: 'Merit, intellectual productivity, commitment, for the first time in the Italian HE history will be really recognised and rewarded.'

As already showed, the British HE policy system seems to reveal the predominance of a centralised managerialism with the consequent loss academic leaders professional autonomy. Not by chance narratives of resistance against the dominant discourse of managerialism have emerged in the form of a critical representation of (gendered) performative regime. Indeed, Italian HE policy system can be read as the result of the conflict between the 'old' bureaucratic and professional discourses and the 'new' managerialist discourses: it still remains rooted in the bureaucratic and professional discourses despite strong transnational reform stimuli (the example of academic leadership represents a significant confirm), with some exception of managerialist 'contamination' (the area of quality assurance constitutes an exception).

Probably for this reason narratives of acceptance of a renovated version of the discourse of merit that the managerialist discursive configuration brought back, have emerged exclusively in the Italian context: the notion of merit places prominence on values such as self-reliance, efficiency, competition and individual success producing normative expectations about what is meant to be a successful academic. Consequently, faith in this idea of an unequivocal 'best person' arises from the belief that merit is a gender-neutral and apolitical variable, reinforcing essentialist discourses about women' styles of leadership, or the naturalisation of the competition among women. As already mentioned, the Italian HE system only recently and in a very contradictory way has imported some 'managerialist recipes'. For these reason, my final hypothesis is that Italian women leaders still believe in the opportunities that the 'new' process of restructuring could offer for women.

\section{Notes}

1. The diversity of the HE contexts selected is also evident when we speak about middle managers. In the British context they are caught in 'discursive tensions' between the managerialist discourse, which press them to become entrepreneurs, their professional heritage, and the wider process of UK universities re-regulation through deregulation, and centralisation through decentralisation (Morley 2003). Differently, Italian middle management failed to see a coherent redefinition of its role in a managerialist sense. Critically reading this process, it is possible to note the Italian case represents a peculiar and hybrid form of re-centralisation without a real decentralisation, where the State is currently re-centralising professional appointments while, at the same time, the power of the 'academic oligarchy' has been reinforced to the detriment of the strategic steering capacity of university management.

2.

Discourses are about the things that can be said, and thought, but also about who can speak, when, where and with what authority. Discourses imply the meaning and use of propositions and words. Thus, certain possibilities of thought are constructed. Words are ordered and combined in particular ways and other combinations are displaced or excluded. (Ball 2006, 48)

3. The 'middle' of the formal university structure in UK usually comprises the Deans of Faculties and/or Heads of Schools or Departments, depending on the university, while in Italy refers to the 'direttori di dipartimento'. As noted above, these positions are 'middle management' in the executive line but also expected to be part of the academic collegium. 
4. For Morley a 'proof' of this absence is that curiously in a culture of measurement and audit in $\mathrm{HE}$, women's representation in different roles and grades is not always perceived as sufficiently important to measure, monitor or map comparatively (Morley 2013).

5. In the EU, for example, She Figures (2009) noted how women's academic careers remain characterised by strong vertical segregation.

6. In this context, and following Watt (1996), I define myth as a popular narration that embodies or symbolises some of the fundamental values of a specific society.

7. The term 'emotional intelligence' gained prominence in the 1995 book by that title, written by the author, psychologist and science journalist Daniel Goleman. He defined emotional intelligence as the array of skills and characteristics that drive leadership performance. More in general, the term is used to describe the ability of an individual to recognise their own and other people's emotions, to discriminate between different feelings and label them appropriately, and to use emotional information to guide thinking and behaviour.

8. In this sense, the persistence of the famous mantra think-manager-think-male (Sinclair 2004) linking the ideal leader as male and masculine paradoxically co-exists with those popular discourses on 'women's styles of leadership'.

9. As Putman and Mumby point out:

Rationality surfaces as the positive while emotionality is viewed as a negative. The prevalence of these dualities contributes to treating emotion as a form of labour, or as a tool of exerting influence in organizational settings. In organizations, emotions are consistently devalued and marginalized while rationality is privileged as an ideal of organizational life. Moreover, the devaluing of emotions and the elevating of rationality results in a particular moral order, one that reflects the politics of the social interaction rather than a universal norm for behaviour. Rationality is typically seen as objective, orderly, and mental while emotionality reflects the chaotic and bodily drives. ( 2000, 39-40)

10. According to de Lauretis, 'Gender as a form of representation and self-representation is constructed by various social technologies, power relations, discourses, epistemologies as well as everyday practices (technologies of gender)' $(1987,2)$.

11. I translated the Italian word 'filibustiera' with the word 'scoundrel'. This particular term is usually reserved for men similarly to the Italian one that expresses the translation of the masculine image of the 'pirate': a 'soldier of fortune', hardened in getting what he wants. It is probably no coincidence that to describe this kind of 'masculine' attitude the figure of the 'filibustiera' has been chosen.

12. In this case the Italian word 'Carabiniere' - Italian police - has been translated as 'police constable' in order to keep the a-gendered connotation of this figure.

\section{Disclosure statement}

No potential conflict of interest was reported by the author.

\section{Notes on contributor}

Emanuela Spanò completed her PhD at the Department of Social Sciences, University of Naples Federico II, Naples, Italy. Her current interests of research concern gender patterns and identity building in the academia field, biographical research, and the intersection of individual biography and society.

\section{References}

Ball, S. J. 2006. Education, Policy and Social Class. London: Routledge. 
Blackmore, J., and J. Sachs. 2007. Performing and Reforming Leaders: Gender, Educational Restructuring and Organisational Change. Albany: State University of New York Press.

Clark, B. 1983. The Higher Education System. Berkeley: University of California Press.

Connell, R. 2006. "The Experience of Gender Change in Public Sector Organisations." Gender, Work and Organization 13 (5): 435-452.

De Lauretis, T. 1987. Technologies of Gender: Essays on Theory, Film and Fiction. Basingstoke: Macmillan Press.

Doherty, L., and S. Manfredi. 2006. "Women's Progression to Senior Positions in English Universities." Employee Relations 28 (6): 553-572.

Fitzgerald, T. 2014. Women Leaders in Higher Education: Shattering the Myths. London: Routledge.

Foucault, M. 1984. Le souci de soi. Paris: Gallimard.

Foucault, M. 1988. "Technologies of the Self." In Technologies of the Self, edited by L. Martin, H. Gutman, and P. Hutton, 16-49. London: Tavistock.

Foucault, M. 1976. La volonté de Savoir. Paris: Gallimard.

Freeman, H. 2013. "Margaret Thatcher was no Feminist." The Guardian, Tuesday April 9. http://www. theguardian.com/commentisfree/2013/apr/09/margaret-thatcher-no-feminist.

Goleman, D. 1995. Emotional Intelligence. New York: Bentham Books.

Hall, D., E. Grimaldi, H. Gunter, J. Møller, R. Serpieri, and G. Skedsmo. 2015. "Educational Reform and Modernisation in Europe: The Role of National Contexts in Mediating the New Public Management." European Educational Research Journal 14 (16): 487-507.

Kay, K., and C. Shipman. 2014. The Confidence Code: The Science and Art of Self-assurance - What Women Should Know. New York Times Bestsellers. New York: Harper Business.

Martin, J. 1990. "Deconstructing Organizational Taboos: The Suppression of Gender Conflict in Organizations." Organization Science 1 (4): 339-359.

Mavin, S. 2006. "Venus Envy 2: Sisterhood, Queen Bees, and Female Misogyny in Management." Women in Management Review 21 (5): 349-364.

Morley, L. 2003. Quality and Power in Higher Education. Buckingham: Open University Press.

Morley, L. 2013. "The Rules of the Game: Women and the Leaderist Turn in Higher Education." Gender and Education 25 (1): 116-131.

Newman, J., and J. Clarke. 2009. Publics, Politics and Power: Remaking the Public in Public Services. London: Sage.

O'Reilly, D., and M. Reed. 2010. "Leaderism: An Evolution of Managerialism in UK Public Service Reform." Public Administration 88 (4): 960-978.

Putnam, L. L., and D. K. Mumby. 2000. "Organisations, Emotion and the Myth of Rationality." In Emotions and Organisations, edited by S. Fineman, 36-57. London: Sage.

Serpieri, R. 2012. Senza leadership: la costruzione del dirigente scolastico. Dirigenti e autonomia nella scuola italiana. Milano: Franco Angeli.

She Figures. 2009. Statistics and Indicators on Gender Equality in Science. Brussels: European Commission.

Sinclair, A. 2004. "Journey Around Leadership." Discourse: Studies in the Cultural Politics of Education 25 (1): 7-19.

Tamboukou, M. 2003. Women, Education and the Self: A Foucauldian Perspective. Basingstoke: Palgrave Macmillan.

UNESCO. 1998. Towards and Agenda for Higher Education: Challenges and Tasks for the 21st Century Viewed in the Light of the Regional Conference. Paris: UNESCO.

Watt, I. 1996. Myths of Modern Individualism: Faust, Don Quixote, Don Juan, Robinson Crusoe. Cambridge: Cambridge University Press. 